\title{
Orthodontic Force Application in Correlation with Salivary Lactate Dehydrogenase Activity
}

\author{
Erik Husin $^{1}$, Rosalina Tjandrawinata ${ }^{2}$, Magdalena Juliani ${ }^{3}$, Boedi O. Roeslan ${ }^{4}$ \\ ${ }^{1}$ Postgraduate Program, Faculty of Dentistry, Trisakti University, Jakarta 11440, Indonesia \\ ${ }^{2}$ Department of Dental Material, Faculty of Dentistry, Trisakti University, Jakarta 11440, Indonesia \\ ${ }^{3}$ Department of Orthodontics, Faculty of Dentistry, Trisakti University, Jakarta 11440, Indonesia \\ ${ }^{4}$ Department of Biochemistry, Faculty of Dentistry, Trisakti University, Jakarta 11440, Indonesia \\ Correspondencee-mail to: erik_husin@yahoo.com
}

\begin{abstract}
Orthodontic tooth movement generate mechanical forces to periodontal ligament and alveolar bone. The forces correlate with initial responses of periodontal tissues and involving many metabolic changes. One of the metabolic changes detected in saliva is lactate dehydrogenase (LDH) activity. Objectives: To evaluate the correlation between orthodontic interrupted force application, lactate dehydrogenase activity and the distance of tooth movement. Methods: One hundred forty samples were collected from 20 subjects, consisted of saliva at pre-extraction of first upper premolar, pre-retraction of upper canine and 1, 7, 14, 21 and 28 days post-retraction of upper canine with $100 \mathrm{~g}$ interrupted orthodontic force. Results: ANOVA showed significant differences between LDH activities and duration of force $(\mathrm{F}=11.926 ; p=0.000)$. Significant differences between pre-retraction of upper canine group and 14 and 28 days post-retraction of canine. The region of retraction correlated with the distance of tooth movement $(\mathrm{F}=7.377 ; p=0.007)$. The duration of force correlated with the distance of tooth movement $(\mathrm{F}=66.554 ; p=0.000)$. The differences were significant between pre-retraction of upper canine group and 1, 7, 14, 21 and 28 days postretraction of canine. Conclusion: This study concluded that orthodontic interrupted force application on canine could increase the distance of tooth movement and LDH activity in saliva.
\end{abstract}

\begin{abstract}
ABSTRAK
Aplikasi gaya ortodonti terhadap aktivitas laktat dehidrogenase dalam saliva. Pergerakan gigi secara ortodonti menghasilkan gaya-gaya mekanik pada jaringan periodontal dan tulang alveolar. Gaya-gaya mekanik ini berhubungan dengan respon awal pada jaringan periodontium and terjadi banyak perubahan-perubahan metabolik. Salah satu perubahan metabolik yang dapat terjadi adalah peningkatan aktivitas enzim laktat dehidrogenase yang dapat dideteksi dalam saliva. Tujuan: Mengetahui korelasi antara pemberian gaya ortodonti dan aktivitas laktat dehidrogenase dalam saliva serta jarak pergerakan gigi. Metode: Penelitian ini mengunakan 140 sampel saliva dari 20 subjek, yaitu saliva yang diambil sebelum pencabutan gigi premolar, sebelum penarikan gigi kaninus rahang atas, 1, 7, 14, 21, dan 28 hari setelah penarikan gigi kaninus dengan gaya ortodonti interrupted sebesar $100 \mathrm{~g}$. Hasil: Analisis ANOVA menunjukkan adanya perbedaan yang bermakna antara aktivitas laktat dehidrogenase dengan durasi pemberian gaya $(\mathrm{F}=11,926 ; p=0,000)$. Perbedaan bermakna juga ditunjukkan pada waktu sebelum dilakukan penarikan gigi kaninus dengan kelompok waktu 14 dan 28 hari. Terdapat kemaknaan antara regio penarikan berpengaruh terhadap jarak pergerakan $(\mathrm{F}=7,377 ; p=0,007)$, dan terdapat pengaruh antara durasi pemberian gaya terhadap jarak pergerakan gigi $(\mathrm{F}=66,554 ; p=0,000)$. Perbedaan bermakna diperlihatkan antara kelompok sebelum penarikan gigi kaninus terhadap kelompok 1, 7, 14, 21, dan 28 hari setelah penarikan gigi kaninus. Simpulan: Aplikasi gaya ortodonti pada gigi kaninus dapat meningkatkan jarak pergerakan gigi dan aktivitas laktat dehidrogenase dalam saliva.
\end{abstract}

Key words: lactate dehydrogenase, orthodontic force, saliva 


\section{INTRODUCTION}

Biomechanic is the major principle in the forces application during orthodontic tooth movement. ${ }^{1}$ Biomechanical response correlates with the changes of applied orthodontic force. Previous studies in biomechanics focused on bone metabolism. ${ }^{2}$ Tooth movement by orthodontic force application is characterized by remodeling changes in dental and paradental tissues including dental pulp, periodontal ligament, alveolar bone and gingival. When these tissues exposed to varying degrees of magnitude, frequency and duration of mechanical loading, they express extensive macroscopic and microscopic changes. $^{3}$

Orthodontic forces induce periodontal ligament and alveolar bone remodeling. It also stimulates inflammation reaction in the periodontal tissue. This reaction triggers alveolar bone resorption and apposition by inflammatory mediators. ${ }^{3}$ The earlier responses of periodontal tissues to mechanical stresses involve several metabolic changes resulted in tooth movement. One of the metabolic changes is an increase activity of lactate dehydrogenase (LDH) which can be detected in saliva. ${ }^{4-7}$ Lactate dehydrogenase is an enzyme normally present in the cytoplasm and release extracellularly when cells undergoing cell death. An increase of lactate dehydrogenase level have been reported during bone remodeling due to orthodontic treatment. ${ }^{8}$ It is believed that lactate dehydrogenase has the potential to be used as a marker for inflammation process during orthodontic treatment. ${ }^{9}$

Previous studies have demonstrated the use of gingival crevicular fluid and saliva for diagnosis of periodontitis..$^{10}$ Research showed that activity of LDH in gingival crevicular fluid (GCF) increased significantly after orthodontic force application. ${ }^{11}$ Although a number of evidences have accumulated on the use of GCF for diagnosis of periodontitis, this approach requires special technique for sampling. In addition, it is difficult to obtain GCF from all site of the dentition. GCF may be acceptable for clinical use but not for epidemiological purposes, and especially not for mass screening. ${ }^{10}$ Recently, saliva has been used for diagnostic purpose because it has wide range of elements for diagnostic. The use of saliva for diagnostic purposes is considered to be less invasive and relatively easy compared to other method. Furthermore, taking saliva as a sample does not cause stress for the patient. ${ }^{10,12}$

Currently, there are three orthodontic force types based on their duration; continuous, interrupted and intermittent forces. Continuous force could be maintained at some appreciable friction of the original from one patient visit to the next. Interrupted force could decline to zero between activation. Intermittent force occur when a force level decline abruptly to zero intermittently once the orthodontic appliance is removed by the patient or when a fixed appliance is temporarily deactivated and return to the original level some time later. The intermittent force could become interrupted between adjustments of the appliance is performed. ${ }^{1}$ The objective of this study was to evaluate the correlation of orthodontic interrupted force application on canine with lactate dehydrogenase activity and the distance of tooth movement. Interrupted force with module chain was used in this study for upper canine retraction.

\section{METHODS}

Twenty orthodontic patients were included in this study. The inclusion criteria were as follows: men or women, age 12-40 years old, required orthodontic treatment with upper first premolar extraction and upper canine retraction, did not have ectopic tooth, good general health of tooth and mouth, good oral hygiene, did not have vertical horizontal bone defects, and did not have consuming all medication or drugs including nonsteroidal anti-inflammatory and antibiotic drugs 1 month before the study period, did not have periodontal diseases and systemic diseases and willing to follow the research procedure by signing the informed consent. The study was initiated after receiving the signed informed consents from the patients. The study protocol was reviewed and approved by The Ethical Committee, Faculty of Dentistry, Trisakti University (No. 26/KE/FKG/05/2011).

For each patient, $100 \mathrm{~g}$ force measured with push-pull gauge (ORMCO ${ }^{\circledR}$ ETM - Lot No.05G46G, USA), was applied to retract upper canine distally. Previous study has reported the optimal force for orthodontic tooth movement was 70-120g. ${ }^{1}$ Close module chain was used and attached from molar band hook to canine bracket hook. The distance of tooth movement was measured from distal side of bracket at lateral incisive to mesial side of bracket at canine using caliper 0.01 mm precision (Mitutoyo, No. NTD12-15PMX, Japan) at the pre-retraction upper canine, 1, 7, 14, 21 and 28 days post-retraction upper canine. The saliva were collected simultaneously for LDH activity comparison. Pre-extraction and pre-retraction LDH activity was measured and used as control groups.

One mL unstimulated saliva was collected using $1.5 \mathrm{~mL}$ tubes. All subjects were asked to rinse the mouth with sterile water for approximately 10 second before saliva collection. The collected saliva samples were directly put on ice, transported to Makmal Terpadu Imunoendokrinologi, Faculty of Medicine, Universitas Indonesia and stored at $-80^{\circ} \mathrm{C}$ freezer. The LDH activity was measured with LDH FS* IFCC reagent (DiaSys Diagnostic System GmbH, D-65558 Holzheim, Germany). The absorbance value were detected with spectrophotometer at $340 \mathrm{~nm}$ 
wavelength (BIO-RAD SmartSpec V3.00.13.e, Italy) at Laboratorium Pengembangan Teknologi Industri Agro dan Biomedika (LAPTIAB) PUSPITEK Serpong. One thousand $\mu \mathrm{L}$ reagent 1 containing phosphate buffer $(50 \mathrm{mmol} / \mathrm{L})$ and pyruvate $(0.60 \mathrm{mmol} / \mathrm{L})$ was incubated at $26^{\circ} \mathrm{C}$ for $1 \mathrm{~min}$. Then reagent 2 (Good's buffer and $\mathrm{NADH}$ ) was added and the sample was incubated at $26^{\circ} \mathrm{C}$ for another $1 \mathrm{~min}$. One hundred $\mu \mathrm{L}$ sample of saliva was taken and put in the spectrophotometer to measure LDH activity. ${ }^{13}$ Statistical analysis of Kolmogorov Smirnov, ANOVA, HSD post hoc Tukey and Pearson Correlation test were used for the study.

\section{RESULTS}

Tooth movement and LDH activity reached their peaks at day 21 (Figure 1 and 2). The duration of force affected the distance of tooth movement $(\mathrm{F}=66.554$, $p=0.000$ ), while the region of retraction correlated with the distance of tooth movement $(\mathrm{F}=7.377, p=0.007)$. It showed that the duration of force affected LDH activity $(\mathrm{F}=11.926, p=0.000)$.

The region of retraction was not correlated with duration of force $(p=1.000)$, distance of tooth movement $(p=0.079)$ nor LDH activity $(p=1.000)$. This study demonstrated the correlation between duration of force with distance of tooth movement $(p=0.000)$ and LDH activity $(p=0.000)$, also the correlation exist between distance of tooth movement with LDH activity $(p=0.000)$.

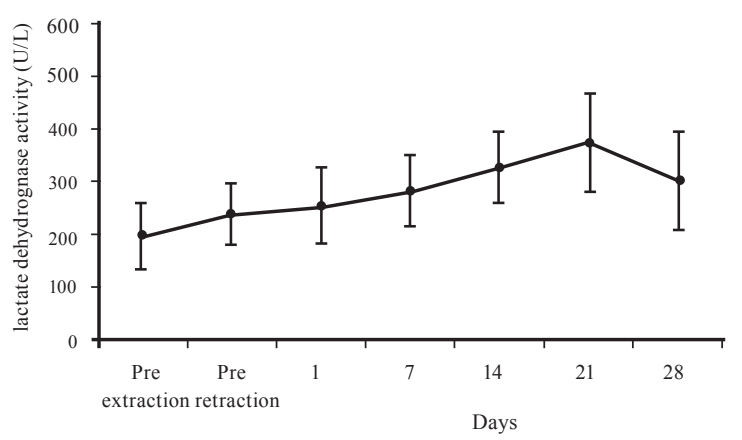

Figure 1. Means and standard deviations of the distance of tooth movement $(\mathrm{mm})$

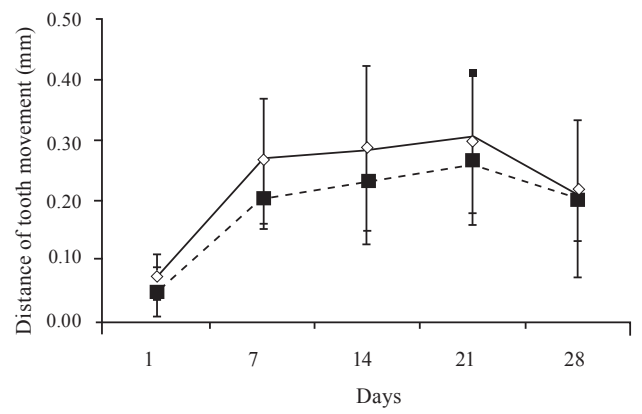

Figure 2. Results of measurement of LDH activity (U/L) at different time after orthodontic force application

\section{DISCUSSION}

Orthodontic tooth movement occurs by the remodeling of the alveolar bone as a result of the force exerted on the periodontal tissue. When a force greater than capillary blood pressure applies to a tooth; hyaline zone occurs in the direction of force. This hyaline zone, free of cells, is necrotic area caused by osteoclast activity that originate from the tension site. On the tension site, osteoblast occur in the bone apposition process. ${ }^{8}$

The bone remodeling that occurs during orthodontic tooth movement is a biologic process involving an acute inflammatory response in the periodontal tissues. The sequence characterized by periods of activation, resorption, reversal, and formation has been recently described as occurring in both tension and compression tooth sites during orthodontic tooth movement. ${ }^{14}$ Orthodontic tooth movement induces a biological process leading to bone resorption in the pressure sites and bone apposition in tension site. Histological studies showed that first a wave of resorption occurred in 3 to 5 days followed by its reversal in 5 to 7 days. This is followed by a late wave of bone formation between 7 and 14 days. ${ }^{11}$

Lactate dehydrogenase, an enzyme normally limited to the cytoplasm of cell, is only released extracellularly after cell death. It is a functionally related intracellular, cytoplasmic enzyme that is release into the extracellular environment upon cell death. Its extracellular presence is related to cell necrosis and tissue breakdown. $\mathrm{LDH}$ activity measured from GCF have also been positively correlate with tissue inflammation during gingivitis and tissue destruction cause by periodontitis in humans. ${ }^{4}$ LDH significantly increased in saliva on patients with periodontal diseases compared to healthy patients. ${ }^{5}$ LDH is a ubiquitous enzyme that plays a significant role in the clinical diagnosis of pathologic processes. Screening periodontal disease by measuring salivary levels of LDH may be feasible, simple and convenient approach that does not require expert examiners. ${ }^{10}$

In this study, the statistical tests showed that the LDH activity is affected by the duration of force. Moreover statistical test results also showed significant differences in LDH activity before and after bracket bonding. The reason might be due to stimulation of plaque retention at the bracket which cause gingival inflammation. The present study was in line with research stated that increment of lactate dehydrogenase activity is often related to tissue inflammation and damage commonly caused by gingivitis and periodontitis respectively. ${ }^{6}$

This research showed that the activity of LDH increased significantly after 7 days; and reached their peak in 21 days by orthodontic force application. This features might occur because the initial wave of absorption is taken place from 3-5 days after the application 
of orthodontic force. This condition is similar with previous studies that showed the increased LDH activity at 7 to 21 days post retraction of canine. ${ }^{11,13}$ Increasing LDH activity was possibly caused by pressure on alveolar bone when canine retraction occurred during orthodontic treatment. Therfore, this LDH might be released since there were cells death during inflammation process. ${ }^{9}$

This study also showed that the duration of orthodontic force affected the distance of tooth movement. Moreover, this study showed that tooth movements can be significantly seen after 7 days application of force. Furthermore, the peak movement of tooth was at 21 days after application of force and after that time the tooth movement is decreased. The initial wave of resorption occurred at 3-5 days after application of orthodontic force and followed by the opposite at 5-7 days and the final wave of resorption occurred at 7 to 14 days which similar to the results of this research was in concordance with previous studies. ${ }^{11}$

The average activity of LDH and tooth movement decreased after 21 days application of orthodontic force. The possibility in decreasing of LDH might be related to the presence of tissue repair and force decays from the module chain. Based on this findings, it might be appropriate to do adjustment of orthodontic appliance after 21 days application of force.

\section{CONCLUSION}

Duration of orthodontic force application influence lactate dehydrogenase activity. Lactate dehydrogenase activity in saliva also correlates with the distance of tooth movement. In conclusion, this study confirmed that, the level of lactate dehydrogenase in whole saliva could also add information about tooth movement activity related to orthodontic treatment.

\section{REFERENCES}

1. Proffit WR, Fields HW, Sarver DM. The biologic basis of orthodontic therapy. In: Proffit WR, editors. Contemporary orthodontics.. 4th ed. St. Louis: Mosby Elsevier; 2007. p.331-58.

2. Robert WE. Application of bioengineering to clinical orthodontics. In: Graber TM and Vanarsdall RL, editors. Orthodontics current principles and techniques. 4th ed. St. Louis: Mosby Elsevier, 2000. p.219.

3. Krishnan V; Davidovitch Z. Cellular, molecular, and tissue-level reactions to orthodontic force. Am J Orthod Dentofac Orthop. 2006;129:1-32

4. Serra E, Perinetti G, D'attilio M. Lactate dehydrogenase activity in gingival crevicular fluid during orthodontic treatment. Am J Orthod Dentofac Orthop. 2003;124:206-11.

5. Koss MA, Castro CE, Salúm KM, López ME. Enzymatic profile of gingival crevicular fluid in association with periodontal status. Lab Med. 2009;40:277-80.

6. Rohaya MAW, Sahidan S, Zaidah ZA, Fahrul ZH, Nuraliza AW, Shahrul HZA. Stability of human salivary lactate dehydrogenase in present of ethylenediaminetetraacetic acid, glycerol, and polyethylene glycol at various temperatures:preliminary study. J Biol Sci. 2010;10:520-5.

7. Todorovic T, Dozic I, Vicente-Barrero M, Ljuskovic B, Pejovic J, Marjanovic M, Knezevic M. Salivary enzymes and periodontal diseases. Med Oral Patol Oral Cir Bucal. 2006;11: E115-9.

8. Kaya FA, Hamamci N, Basaran G, Dogru M, Yildirim TT. TNF- $\alpha$, IL-1 $\beta$ and IL- 8 levels in tooth early leveling movement orthodontic treatment. J Int Dent Med Res. 2010;3:116-21.

9. Shahrul HZA, Mohdfaiz E, Rohaya MAW, Yosni B, Sahidan S. Profiles of lactate dehydrogenase, tartrate resistant acid phosphatase and alkaline photophatase in saliva during orthodontic treatment. Sains Malays. 2010;39:405-12.

10. Nomura Y, Tamaki Y, Tanaka T, Arakawa H, Tsurumoto A, Kirimura K, Sato T, Hanada N, Kamoi K. Screening of periodontitis with salivary enzyme tests. J Oral Sci. 2006;48:177-83.

11. Alfaqeeh SA, Anil S. Lactate dehydrogenase activity in gingival crevicular fuid as a marker in orthodontic tooth movement. Open Dent J. 2011;5:105-9.

12. Koh DSQ, Koh GC. The use of salivary biomarkers in occupational and environmental medicine. Occup Environ Med. 2007;64:202-10.

13. Santoso L. Aktivitas laktat dehidrogenase di dalam cairan celah gusi kaninus pada pergerakan ortodonti [thesis]. 2009. Jakarta: Universitas Trisakti. Indonesian.

14. Wise, GE, King GJ. Mechanisms of tooth eruption and orthodontic tooth movement. J Dent Res. 2008;87:414-34. 